Article

\title{
Rainfall Intensity-Duration-Frequency Relationships for Risk Analysis in the Region of Matopiba, Brazil
}

\author{
Luciele Vaz da Silva ${ }^{1}$, Derblai Casaroli ${ }^{2}$, Adão Wagner Pêgo Evangelista ${ }^{2}$, José Alves Júnior ${ }^{2}$, \\ Rafael Battisti ${ }^{2}$ \\ ${ }^{1}$ Faculdade Central de Cristalina, Cristalina, GO, Brasil. \\ ${ }^{2}$ Escola de Agronomia, Universidade Federal de Goiás, Goiânia, GO, Brasil.
}

Received: 4 June 2018 - Accepted: 31 October 2018

\begin{abstract}
The region of study was MATOPIBA, located in the north of Brazilian Savanna biome (Cerrado), encompassing part of north/northeast of Brazil. The region has been gaining prominence in the last years due to the expansion of agricultural over this area. The aims of this study were: to adjust parameters for rainfall intensity-duration-frequency; and to identify the most vulnerable agricultural areas to erosion based on erosivity and erodibility. The rainfall intensity-duration-frequency function were adjusted using series of maximum annual rainfall event from 105 rainfall gauges. Gumbel model was the most efficient to simulate the maximum rainfall intensity, where these data were used to adjusted the rainfall intensity-duration-frequency model based on $\mathrm{K}, \mathrm{a}, \mathrm{b}$ and c parameters. The most rainfall gauges showed intensity between 51 and $80 \mathrm{~mm} \mathrm{~h}^{-1}$ and 81 and $120 \mathrm{~mm} \mathrm{~h}^{-1}$, respectively, for return period of 2 and 100 years with rainfall duration of 30 minutes. The higher rainfall intensity was observed mainly in the central-north of the region associated with rainfall systems. The rainfall intensity showed a huge capacity to cause soil erosion based on the erosivity energy, while the moderate erodibility was observed for areas with Ferralsols and Leptosols and low erodibility for areas with Arenosols.
\end{abstract}

Keywords: Gumbel model, return years, soil erosion, erosivity, erodibility, Brazilian Savanna.

\section{Relação Intensidade-Duração-Frequencia de Chuva para Analise de Risco na Região do Matopiba, Brasil}

\begin{abstract}
Resumo
A região de estudo foi o MATOPIBA, localizado no norte do Cerrado Brasileiro. Esta região vem ganhando destaque pela expansão de área agrícolas nos últimos anos. Desta forma, o objetivo deste estudo foi ajustar parâmetros para estimativa da intensidade-duração-frequência de chuva, e identificar áreas agrícolas com maior risco de erosão baseado nos índices de erosividade e erodibilidade. As funções de intensidade-duração-frequência de chuva foram ajustadas usando series de valor máximo de chuva de 105 estações pluviométricas. O modelo Gumbel foi o que melhor simulou a distribuição de máxima intensidade de chuva, usada para ajustar os coeficientes $\mathrm{K}$, a, b e c da relação intensidade-duraçãofrequência. A maioria das estações obteve intensidades entre 51 e $80 \mathrm{~mm} \mathrm{~h}^{-1}$, e 81 e $120 \mathrm{~mm} \mathrm{~h}^{-1}$, respectivamente, para período de retorno de 2 e 100 anos com duração de 30 minutos. As maiores intensidades foram observadas na região central-norte, que está associada ao sistemas de chuvas. A intensidade de chuva mostrou-se capaz de causar elevado risco de erosão, considerando a energia de erosividade. Enquanto que erodibilidade apresentou moderado risco para latossolos e neossolos litólicos, e baixo para neossolos quartzarênicos.
\end{abstract}

Palavras-chave: modelo Gumbel, anos de retorno, erosão do solo, erosividade, erodibilidade, cerrado.

\section{Introduction}

The MATOPIBA is a region located in the north of Brazilian Savanna biome (Cerrado), comprising the most of Maranhão (MA) and Tocantins (TO) states, and the Southwest of Piauí (PI) and West of Bahia (BA) states. The region has been gaining prominence in the recent

Autor de correspondência: Rafael Battisti, battisti@ufg.br. 
years due to the expansion of agricultural over this area. The MATOPIBA represented $9.28 \%$ of grain production in Brazil, with a total area of over 7 million hectares (MAPA, 2017). The main crops grown are soybean, cotton, maize and rice (CONAB, 2018).

The climate was classified as Aw (tropical zone with dry winter) in the most of area, following the Köppen climate classification (Alvares et al., 2013). The rainfall is concentrated from October to April, totalizing between 1000 and $1600 \mathrm{~mm} \mathrm{year}^{-1}$ (INMET, 2017). The higher rainfall quantity falling in a short period increase the risk of erosion in agricultural areas (Wu et al., 2017) and water losses (Wang et al., 2015). The risk of erosion and water losses can be reduced with a better plan of hydraulic works in the agriculture.

Hydraulic works in agriculture include erosion control, dump spillways, drainage systems and stormwater galleries (Damé et al., 2012). The efficiency of these systems goes through a good planning based on temporal and spatial rainfall intensity-duration-frequency. The intensityduration-frequency relationships are used to characterize the maximum rainfall patterns (Oliveira et al., 2005), which is essential to dimension the size of the structure in agriculture to reduce erosion and water losses.

The soil characteristics are other important point for analyze the risk of erosion and water losses. The Universal Soil Loss Equation was developed based on five factors, being: erosivity, erodibility, slope steepness and length, land use and cropping management, and control erosion practices (Nearing et al., 2017). Erosivity represents the maximum energy of rainfall per unit of rainfall depth, related with maximum rainfall intensity in 30 minutes (Zheng and Chen, 2015), while erodibility represent the soil erosion susceptibility in function of soil texture and structure, organic matter content and soil permeability (Jones et al., 1996).

This way, the aims of this study were: 1) to adjusted parameters for intensity-duration-frequency relationship from daily rainfall disaggregation; 2) to determine the maximum rainfall intensity in 30 minutes for return period of 2, 5, 10, 25, 50 and 100 years; and 3) to analyses the most vulnerable agricultural areas to erosion based on erosivity and erodibility in the region of MATOPIBA, Brazil.

\section{Material and Methods}

\subsection{Study area}

The region of study were the main agricultural areas in the MATOPIBA, including the South of Maranhão (MA) state, the Northeast of Tocantins (TO) state, the Central-South of Piauí (PI) state, and West of Bahia (BA) state in Brazil (Fig. 1). The climate was classified as a tropical zone with dry winter (Aw) for the most of the area, and tropical zone with dry summer (As) for a small region in the Southeast, following the Köppen climate classification (Alvares et al., 2013). Annual rainfall range between 1000 and $1600 \mathrm{~mm} \mathrm{year}^{-1}$, occurring mostly between October and April (INMET, 2017).

\subsection{Rainfall data}

Rainfall data were obtained from the National Hydrometeorological Network of the National Water Agency (ANA, 2014) for 105 gauges located in 35 cities. The period of daily record rainfall ranged from 15 to 65 years along the sites. A consistency analysis was done to eliminate rainfall gauges with less than 15 years of records and with missing data. The 15 years of records is a minimum data considered by MAPA (2018) for agricultural zoning, which defined the adaptability of a region for agricultural purposes. The rainfall series showed to be stationarity, which was verify by linear regression and the level of significance. In each hydrological year was selected the higher rainfall event occurred in one day to build the series of probability distribution for the maximum rainfall intensity, which make each maximum event independent.

\subsection{Rainfall disaggregation}

The maximum rainfall intensity was estimated based on the relationship between the total rainfall and the period. The maximum rainfall intensity was disaggregated

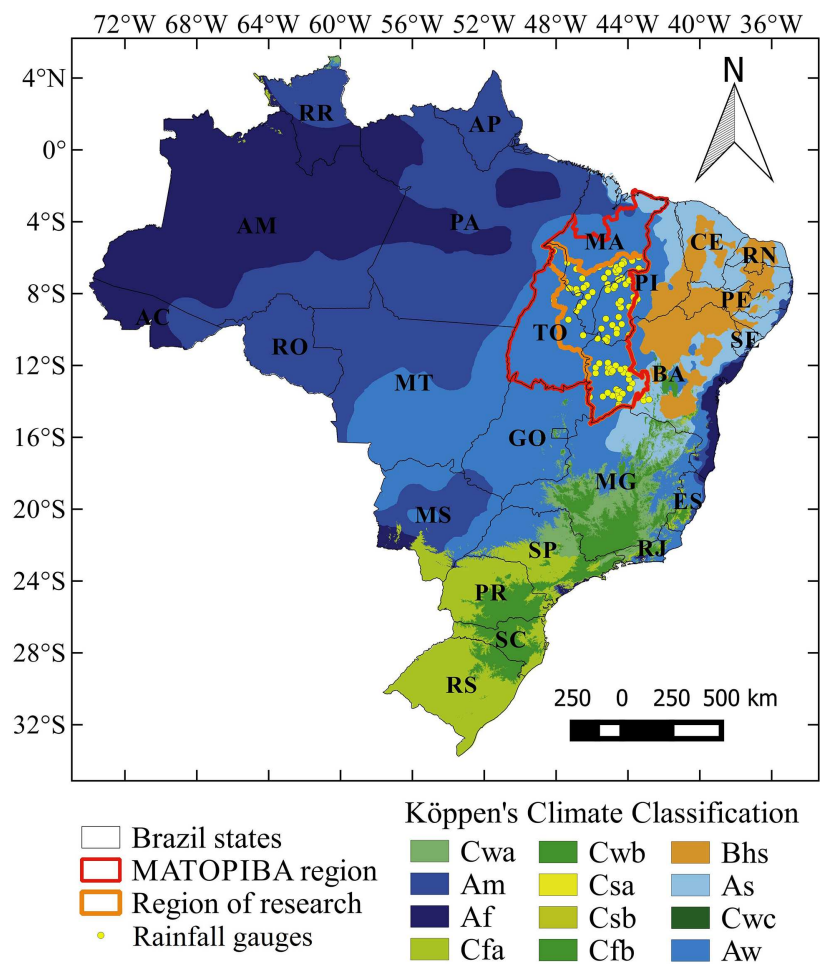

Figure 1 - Köppen's climate classification, location of rainfall gauges, and delimitation of MATOPIBA and research region. Adapted from Alvares et al. (2013). 
from a daily period to 1440 minutes, from $1440 \mathrm{~min}$ to $720,600,480,360$ and 60 minutes, from 60 minutes to 30 , and from 30 minutes to $25,20,15,10$ and 5 minutes. The rainfall disaggregation was done by multiplying the reference value for a proportion coefficient adjusted in DAAECESTESB (1980), which was used by different authors for the Cerrado biome (Oliveira et al. 2005; 2008; Campos et al., 2014). The use of general parameters was did due to the rainfall data were obtained daily and there was no data available for the region at a smaller frequency to generate an appropriated rainfall disaggregation for the regional condition, as recommended by Koutsoyiannis et al. (1998).

\subsection{Modelling intensity-frequency-duration (IFD) curves}

The maximum rainfall intensity was submitted to the statistical analysis to adjust the best probabilistic model, considering different rainfall duration (1440, 720, 600, $480,360,60,30,25,20,15,10$ and 5 minutes). Gumbel, Log-Normal with 2 and 3 parameters, Pearson and LogPearson III were the models tested for the maximum rainfall intensity in the pre-analysis. The Gumbel model showed the best performance between the tested models based on chi-square test.

After obtained the Gumbel parameters for maximum rainfall intensity and duration, the inverse of Gumbel was used to calculate the maximum rainfall intensity for different duration and return period, as present in Eq. (1).

$$
\begin{aligned}
i_{j} & =\left(i_{\text {mean }}-0.557 * \sqrt{\frac{v a r}{1.645}}\right)-\left(\sqrt{\frac{v a r}{1.645}}\right) \\
& * \operatorname{Ln}\left(\operatorname{Ln} \frac{R p}{R p-1}\right)
\end{aligned}
$$

where: $i_{j}\left(\mathrm{~mm} \mathrm{~h}^{-1}\right)$ is the maximum rainfall intensity for the duration period of $1440,720,600,480,360,60,30$, $25,20,15,10$ and 5 minutes, and return periods of 2, 5, $10,25,50$ and 100 years; $i_{\text {mean }}\left(\mathrm{mm} \mathrm{h}^{-1}\right)$ and var are, respectively, the mean and the variance of maximum annual rainfall intensity for the entire series records in the rainfall gauge for each duration period and return periods; and $\mathrm{Rp}$ (years) is the return period.

The IFD curves were adjusted based on the simulated series of probability distribution based on inverse of Gumbel model for the maximum rainfall intensity, considering rainfall duration of 1440, 720, 600, 480, 360, 60, $30,25,20,15,10$ and 5 minutes, and return periods of 2 , 5, 10, 25, 50 and 100 years, using Eq. (2). The K, a, b and c parameters were adjusted for the IFD probabilistic model using the minimum squares method.

$$
i_{\text {max } S}=\frac{K R p^{a}}{(t+b)^{c}}
$$

where: $\mathrm{i}_{\operatorname{maxS}}\left(\mathrm{mm} \mathrm{h}^{-1}\right)$ is the maximum rainfall intensity simulated $\left(\mathrm{mm} \mathrm{h}^{-1}\right) ; \mathrm{Rp}$ is the return period (years); $\mathrm{t}$ is the period of rainfall duration (minutes), and $\mathrm{K}, \mathrm{a}, \mathrm{b}$ and $\mathrm{c}$ are adjusted parameters for each rainfall gauge.

The results for IFD curves were compared against observed maximum rainfall intensity to analyze their performance. The statistical indexes used to analyze the model performance were: mean absolute error (MAE), root mean square error (RMSE), determination coefficient $\left(\mathrm{r}^{2}\right)$ and Willmott coefficient $(\mathrm{d})$.

\subsection{Erosion risk analysis}

Erosivity and erodibility indexes were used to identify the most vulnerable agricultural areas to erosion and water losses, based on the Universal Soil Loss Equation (Nearing et al., 2017). The erosivity was quantified based on the maximum 30 minutes rainfall intensity, using the Gumbel model with parameters adjusted for each rainfall gauge for the return period of 2, 5, 10, 25, 50 and 100 years. The maximum rainfall 30 minutes intensity was used due to better correlation with soil losses for a single rainfall event (Wischmeier et al., 1958; Zheng and Chen, 2015). The erodibility value was obtained based on the soil type (IBGE, 2012) and the soil texture (RADAM, 1974), following Wanielista (1978), and the risk level, following Jones et al. (1996). The others parameters of Universal Soil Loss Equation were not included in the analysis due to limitation of information to compute the risk of erosion.

\section{Results and Discussions}

\subsection{IFD curves model}

The maximum rainfall intensity distribution was adjusted using the Gumbel probabilistic model, which had the best fit between pre-tested models. Gumbel probabilistic model is the most widely used for rainfall intensityduration-frequency relationship (Koutsoyiannis et al., 1998; Beskow et al., 2015). The model was used to describe the maximum rainfall distribution in different sites around world, as in Saudi Arabia (Elsebaie, 2012), Israel (Ben-Zvi, 2009) and south of Brazil (Cardoso et al., 2014).

The IFD model had $\mathrm{r}^{2}$ and $\mathrm{d}$ coefficients above 0.9798, with the highest mean absolute error (MAE) and root mean square error (RMSE), respectively, of $8.15 \mathrm{~mm}$ $\mathrm{h}^{-1}$ and $10.41 \mathrm{~mm} \mathrm{~h}^{-1}$ in the site of Barreiras (Data not showed), which was the longest rainfall gauge records (65 years), when compared observed and simulated values. The model efficiency was kept in Colinas, which had only 15 years of full rainfall records (Data not showed). In this site, the $\mathrm{r}^{2}$ and $\mathrm{d}$ coefficients were above 0.9830 , with the highest MAE and RMSE, respectively, of $8.77 \mathrm{~mm} \mathrm{~h}^{-1}$ and $11.19 \mathrm{~mm} \mathrm{~h}^{-1}$. The good fit also was observed for the other rainfall gauges used in the study (Data not showed). 


\subsection{IFD model parameters}

The IFD model was adjusted based on the $\mathrm{K}, \mathrm{a}, \mathrm{b}$ and $\mathrm{c}$ parameters for the rainfall gauges to estimate rainfall intensity in different return periods and rainfall duration. The K, a, b, and c parameters were adjusted for each rainfall gauge in the states of Tocantins (Table 1), Maranhão (Table 2), Piauí (Table 3) and Bahia (Table 4). The b and c were parameters stable between the analyzed sites, where $\mathrm{b}$ ranged between 9.760 and 10.514, and c between 0.725 and 0.745 . The parameters $b$ and $c$ lead a reduction of rainfall intensity when theirs values were higher.

The $\mathrm{K}$ and a parameters had higher variation between the rainfall gauges (Table 1, 2, 3 and 4), where higher values for these parameters increased rainfall intensity. The K parameter ranged between 552 and 1169, occurring, respectively, in the rainfall gauge of Matina, Bahia state (Table 4), and Vereda Grande, Maranhão state (Table 2). The parameter a varied between 0.10 , for the rainfall gauge of Ibipira, Maranhão state (Table 2) and São Sebastião do Tocantinas, Tocantins state (Table 1), and 0.26, in Eliseu Martins, Piauí state (Table 3).

\subsection{Rainfall intensity}

The sites of Barreiras and Colinas were used as a case of study, due to be the longest and shortest rainfall records, respectively, of 65 and 15 years. The rainfall intensity was 59 and $120 \mathrm{~mm} \mathrm{~h}^{-1}$ in 30 minutes in Barreiras, respectively, for return period of 2 and 100 years (Fig. 2a). In Colinas, the rainfall intensity was higher, being 69 and $134 \mathrm{~mm} \mathrm{~h}^{-1}$ in 30 minutes, respectively, for return period of 2 and 100 years. In the south of Brazil, Cardozo et al. (2014) observed lower maximum rainfall intensity, being of $47 \mathrm{~mm} \mathrm{~h}^{-1}$ in 30 minutes for return period of 2 years. Longer return periods increased rainfall intensity (Figs. 2-3), as observed by other authors (Elsebaie, 2012; Cardoso et al., 2014; Tfwala et al., 2017).

Rainfall intensity was 310 and $347 \mathrm{~mm} \mathrm{~h}^{-1}$, respectively, for Barreiras and Colinas, for a rainfall of 1 minute and return period of 100 years (Fig. 2). Otherwise, rainfall

Table 1 - Parameters values obtained for estimate rainfall intensity-frequency-duration curves for cities in Tocantins state

\begin{tabular}{lccccc}
\hline Cities & Rainfall gauges & \multicolumn{4}{c}{ Parameters } \\
\cline { 3 - 6 } & & $\mathrm{k}$ & $\mathrm{a}$ & $\mathrm{b}$ & $\mathrm{c}$ \\
\hline Araguatins & Araguatins & 1037 & 0.140 & 9.790 & 0.730 \\
Campos Lindos & Campos Lindos & 873 & 0.150 & 9.800 & 0.730 \\
Goiatins & Goiatins & 850 & 0.120 & 9.800 & 0.730 \\
Rio Sono & Mansinha & 1005 & 0.150 & 9.790 & 0.730 \\
São Felix & São Felix & 757 & 0.160 & 9.790 & 0.730 \\
S. S. do Tocantins & S. S. do Tocantins & 951 & 0.100 & 9.800 & 0.730 \\
Tocantinópolis & Tocantinópolis & 965 & 0.140 & 9.790 & 0.730 \\
Tupiratins & Tupiratins & 912 & 0.160 & 9.790 & 0.730 \\
\hline & & & & &
\end{tabular}

intensity dropped to 9 and $10 \mathrm{~mm} \mathrm{~h}^{-1}$, respectively, for Barreiras and Colinas, when the rainfall had a duration of 24 hours. The reduction of rainfall intensity with longer raining period is an expected tendency, but the intensity was related with local climate (Elsebaie, 2012; Cardoso et al., 2014; Tfwala et al., 2017). For example, Elsebaie et al. (2012) observed maximum rainfall intensity reducing from $38 \mathrm{~mm} \mathrm{~h}^{-1}$ in 10 minutes, to $1.74 \mathrm{~mm} \mathrm{~h}^{-1}$ in 24 hours, for return period of two years in Najran region, Saudi Arabia.

Table 2 - Parameters values obtained for estimate rainfall intensity-frequency-duration curves for cities in Maranhão state

\begin{tabular}{|c|c|c|c|c|c|}
\hline \multirow[t]{2}{*}{ Cities } & \multirow[t]{2}{*}{ Rainfall gauges } & \multicolumn{4}{|c|}{ Parameters } \\
\hline & & $\mathrm{k}$ & a & $\mathrm{b}$ & c \\
\hline \multirow[t]{10}{*}{ Balsas } & Amaro Leite & 886 & 0.190 & 9.790 & 0.730 \\
\hline & Balsas I & 914 & 0.210 & 9.790 & 0.730 \\
\hline & Balsas II & 840 & 0.170 & 9.760 & 0.730 \\
\hline & Balsas III & 963 & 0.160 & 9.790 & 0.730 \\
\hline & B. Com. Boto & 810 & 0.130 & 9.790 & 0.730 \\
\hline & Brejo Comprido & 942 & 0.150 & 9.800 & 0.730 \\
\hline & Croata & 801 & 0.150 & 9.800 & 0.730 \\
\hline & Ouro & 739 & 0.150 & 9.800 & 0.730 \\
\hline & Rio Verde & 800 & 0.160 & 9.790 & 0.730 \\
\hline & S. Félix de Balsas & 780 & 0.140 & 9.790 & 0.730 \\
\hline \multirow[t]{2}{*}{ Loreto } & Loreto & 736 & 0.163 & 9.791 & 0.725 \\
\hline & Mato Grosso & 815 & 0.139 & 9.790 & 0.725 \\
\hline Benedito Leite & São Domingos & 661 & 0.150 & 9.790 & 0.730 \\
\hline \multirow[t]{4}{*}{ Carolina } & Carolina I & 891 & 0.130 & 9.790 & 0.730 \\
\hline & Carolina II & 901 & 0.170 & 9.790 & 0.730 \\
\hline & Faz. dos Angicos & 946 & 0.140 & 9.790 & 0.730 \\
\hline & Helenópolis & 854 & 0.145 & 9.790 & 0.725 \\
\hline \multirow[t]{3}{*}{ Colinas } & Colinas I & 901 & 0.171 & 9.788 & 0.725 \\
\hline & Colinas II & 855 & 0.152 & 9.791 & 0.725 \\
\hline & Colinas III & 869 & 0.161 & 9.795 & 0.725 \\
\hline \multirow[t]{3}{*}{ Barão de Grajaú } & Barão de Grajaú & 818 & 0.150 & 9.790 & 0.730 \\
\hline & Lages & 887 & 0.150 & 9.790 & 0.730 \\
\hline & Morro Vermelho & 767 & 0.160 & 9.800 & 0.730 \\
\hline Nova Iorque & Nova Iorque II & 916 & 0.150 & 9.790 & 0.730 \\
\hline \multirow[t]{6}{*}{ Mirador } & Campo Largo I & 898 & 0.124 & 9.787 & 0.725 \\
\hline & Campo Largo II & 922 & 0.170 & 9.782 & 0.725 \\
\hline & Ibipira & 911 & 0.101 & 9.790 & 0.725 \\
\hline & José Miguel & 809 & 0.120 & 9.790 & 0.730 \\
\hline & Mirador I & 748 & 0.140 & 9.790 & 0.730 \\
\hline & Mirador II & 809 & 0.150 & 9.790 & 0.730 \\
\hline \multirow[t]{2}{*}{ Passagem Franca } & Passagem Franca & 868 & 0.170 & 9.790 & 0.730 \\
\hline & Vereda Grande & 1169 & 0.190 & 9.790 & 0.730 \\
\hline Porto Franco & São Pedro & 684 & 0.210 & 9.800 & 0.730 \\
\hline Riação & Coqueiro & 845 & 0.120 & 9.790 & 0.730 \\
\hline Sambaiba & Sambaiba & 805 & 0.150 & 9.790 & 0.730 \\
\hline
\end{tabular}


Table 3 - Parameters values obtained for estimate rainfall intensity-frequency-duration curves for cities in Piauí state

\begin{tabular}{|c|c|c|c|c|c|}
\hline \multirow[t]{2}{*}{ Cities } & \multirow[t]{2}{*}{ Rainfall gauges } & \multicolumn{4}{|c|}{ Parameters } \\
\hline & & $\mathrm{k}$ & a & $\mathrm{b}$ & $\mathrm{c}$ \\
\hline \multirow{2}{*}{ Avelino Lopes } & Avelino Lopes & 668 & 0.175 & 9.797 & 0.725 \\
\hline & Vereda da Mata & 703 & 0.141 & 9.787 & 0.725 \\
\hline \multirow[t]{3}{*}{ Bom Jesus } & Barra verde & 664 & 0.246 & 9.797 & 0.725 \\
\hline & Bom Jesus & 720 & 0.198 & 9.794 & 0.725 \\
\hline & Conceição & 611 & 0.219 & 9.792 & 0.725 \\
\hline \multirow[t]{4}{*}{ Corrente } & Barra & 580 & 0.209 & 9.798 & 0.725 \\
\hline & Caxingo & 751 & 0.135 & 9.788 & 0.725 \\
\hline & Corrente & 825 & 0.166 & 9.795 & 0.725 \\
\hline & Jenipapeiro & 808 & 0.182 & 9.793 & 0.725 \\
\hline Cris.do Piauí & Cristalândia do Piauí & 826 & 0.162 & 9.792 & 0.725 \\
\hline \multirow[t]{2}{*}{ Cristino Castro } & Japecanga & 627 & 0.178 & 9.793 & 0.725 \\
\hline & Lagoa Grande & 556 & 0.226 & 9.792 & 0.725 \\
\hline \multirow[t]{3}{*}{ Eliseu Martins } & Chupeiro & 842 & 0.192 & 9.789 & 0.725 \\
\hline & Eliseu Martins & 981 & 0.261 & 9.792 & 0.725 \\
\hline & Puca I & 737 & 0.148 & 9.848 & 0.726 \\
\hline \multirow[t]{2}{*}{ Landri Sales } & Cascavel & 780 & 0.142 & 9.796 & 0.725 \\
\hline & Landri Sales & 1067 & 0.161 & 9.793 & 0.725 \\
\hline Barreiras do Piuaí & Barreiras do Piuaí & 841 & 0.159 & 9.794 & 0.725 \\
\hline \multirow[t]{2}{*}{ Monte Alegre } & Brejo & 554 & 0.189 & 9.937 & 0.729 \\
\hline & Vereda da Glória & 800 & 0.152 & 9.788 & 0.725 \\
\hline \multirow[t]{2}{*}{ Parnaguá } & Barreiros & 751 & 0.133 & 9.790 & 0.725 \\
\hline & Parnaguá & 706 & 0.156 & 9.795 & 0.725 \\
\hline \multirow[t]{4}{*}{ Uruçuí } & Puca II & 754 & 0.160 & 9.800 & 0.730 \\
\hline & Sangue & 872 & 0.160 & 9.790 & 0.730 \\
\hline & Tucuns & 799 & 0.160 & 9.790 & 0.730 \\
\hline & Urucuí & 790 & 0.200 & 9.799 & 0.725 \\
\hline
\end{tabular}

The most rainfall gauges had a rainfall intensity between 51 and $80 \mathrm{~mm} \mathrm{~h}^{-1}$, when considered return period of 2 years, with only two sites with rainfall intensity between 81 and $120 \mathrm{~mm} \mathrm{~h}^{-1}$ (Fig. 3a). There was an increase of sites with rainfall intensity between 81 and $120 \mathrm{~mm} \mathrm{~h}^{-1}$, from 2 , for return period of 2 years, to 13 , for return period of 5 years (Fig. 3b). The rainfall intensity between 121 and $160 \mathrm{~mm} \mathrm{~h}^{-1}$ had the first occurrence for return periods of 10 years in the northeast of the regions, with a total of two sites (Fig. 3c).

The most sites had rainfall intensity between 81 and $120 \mathrm{~mm} \mathrm{~h}^{-1}$ for return periods of 25 years (Fig. 3d). The rainfall intensity below $80 \mathrm{~mm} \mathrm{~h}^{-1}$ occurred only in three sites for return periods of 50 years, with most sites with rainfall intensity between 81 and $120 \mathrm{~mm} \mathrm{~h}^{-1}$. The first occurrence of rainfall intensity above $160 \mathrm{~mm} \mathrm{~h}^{-1}$ occurred in the return periods of 50 years in two sites in the northeast of the study regions (Fig. 3d). For return periods of 100 years, it was observed an increase of sites with
Table 4 - Parameters values obtained for estimate rainfall intensity-frequency-duration curves for cities in Bahia state

\begin{tabular}{|c|c|c|c|c|c|}
\hline \multirow[t]{2}{*}{ Cities } & \multirow[t]{2}{*}{ Rainfall gauges } & \multicolumn{4}{|c|}{ Parameters } \\
\hline & & $\mathrm{k}$ & $\mathrm{a}$ & $\mathrm{b}$ & $\mathrm{c}$ \\
\hline \multirow[t]{8}{*}{ Santana } & Campinas & 684 & 0.159 & 9.792 & 0.725 \\
\hline & Faz. Baixa Funda & 796 & 0.117 & 9.792 & 0.725 \\
\hline & Faz. Moço & 626 & 0.175 & 9.792 & 0.725 \\
\hline & Faz. Tabuinha & 704 & 0.171 & 10.514 & 0.745 \\
\hline & Jaguará & 761 & 0.157 & 9.798 & 0.725 \\
\hline & Matina & 552 & 0.154 & 9.792 & 0.725 \\
\hline & Porto Novo & 629 & 0.198 & 9.793 & 0.725 \\
\hline & Porto Novo II & 688 & 0.158 & 9.793 & 0.725 \\
\hline Angical & Angical & 739 & 0.166 & 9.792 & 0.725 \\
\hline \multirow[t]{2}{*}{ Brejolândia } & Brejolândia & 707 & 0.159 & 9.791 & 0.725 \\
\hline & Três Morros & 696 & 0.153 & 9.790 & 0.725 \\
\hline Serra Dourada & Serra Dourada & 782 & 0.146 & 9.790 & 0.725 \\
\hline \multirow[t]{3}{*}{ São Desidério } & Decoral & 774 & 0.129 & 9.795 & 0.725 \\
\hline & Sítio Grande & 783 & 0.134 & 9.793 & 0.725 \\
\hline & Faz. Coqueiro & 868 & 0.156 & 9.797 & 0.725 \\
\hline \multirow[t]{6}{*}{ Barreiras } & Barreiras & 769 & 0.178 & 9.790 & 0.725 \\
\hline & Faz. Joha & 765 & 0.139 & 9.802 & 0.725 \\
\hline & Faz. Redenção & 804 & 0.159 & 9.790 & 0.725 \\
\hline & V. N. Montante & 725 & 0.120 & 9.790 & 0.730 \\
\hline & Ponte Serafim & 819 & 0.191 & 9.791 & 0.725 \\
\hline & Santa Helena & 712 & 0.169 & 9.791 & 0.725 \\
\hline \multirow[t]{3}{*}{ Cocos } & Cocos & 740 & 0.182 & 9.797 & 0.725 \\
\hline & Faz. Porto Alegre & 786 & 0.148 & 9.798 & 0.725 \\
\hline & Colônia do Formoso & 797 & 0.166 & 9.789 & 0.725 \\
\hline \multirow[t]{9}{*}{ Correntina } & Arrojolândia & 786 & 0.148 & 9.798 & 0.725 \\
\hline & Correntina I & 751 & 0.152 & 9.791 & 0.725 \\
\hline & Correntina II & 786 & 0.148 & 9.798 & 0.725 \\
\hline & Faz. Planalto & 774 & 0.168 & 9.791 & 0.725 \\
\hline & Faz. Prainha & 755 & 0.163 & 9.797 & 0.725 \\
\hline & São Manuel & 737 & 0.137 & 9.791 & 0.725 \\
\hline & Arrojado & 786 & 0.148 & 9.798 & 0.725 \\
\hline & S. S. dos Gatos I & 722 & 0.150 & 9.793 & 0.725 \\
\hline & S. S. dos Gatos II & 659 & 0.170 & 9.793 & 0.725 \\
\hline Coribe & Coribe & 612 & 0.172 & 9.794 & 0.725 \\
\hline Cristópolis & Buritizinho & 694 & 0.156 & 9.789 & 0.725 \\
\hline Catolândia & Catolândia & 841 & 0.142 & 9.798 & 0.725 \\
\hline
\end{tabular}

rainfall intensity between 121 and $160 \mathrm{~mm} \mathrm{~h}^{-1}$ in relation to return periods of 50 years, mainly in the central-north (Fig. 3f).

In the central-north of MATOPIBA, the Intertropical Convergence Zone contributes for the highest rainfall intensity. The position of this convergence zone is affect by sea surface temperature in North and South Atlantic Sea. When the zone is under MATOPIBA, the rainfall is 

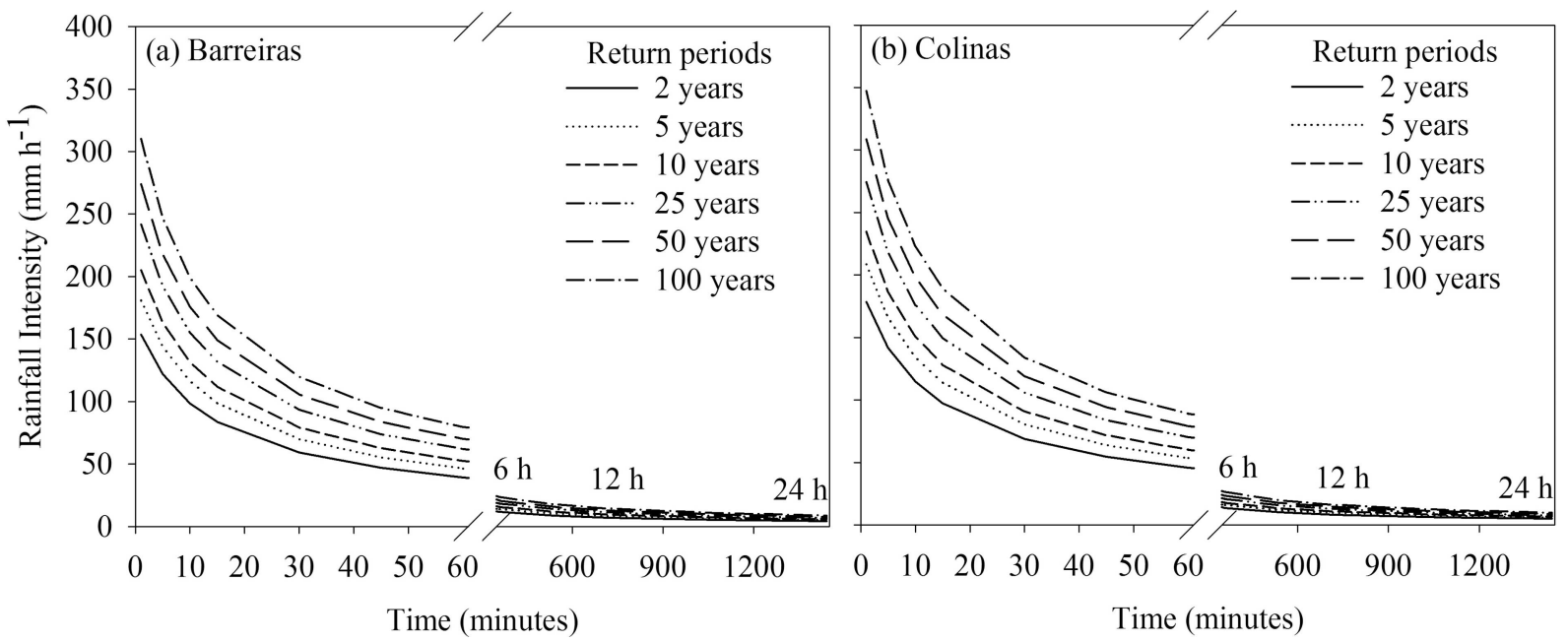

Figure 2 - Simulated rainfall intensity for return periods of 2 (a), 5 (b), 10 (c), 25 (d), 50 (e) and 100 (f) years and raining period between 1 and 1440 minutes by Gumbel model in Barreiras (a) and Colinas (b).
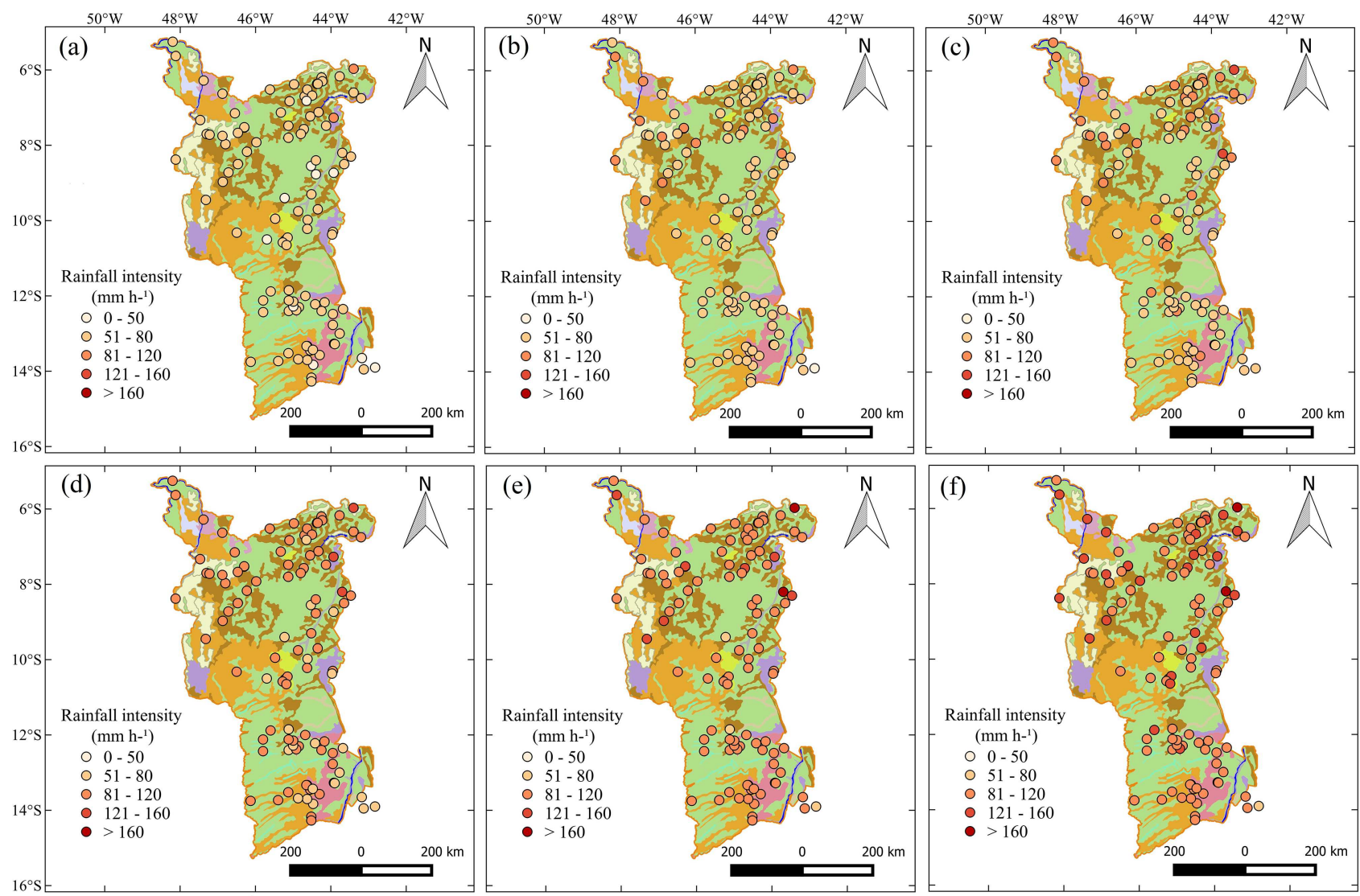

$\square$ Ferralsols $\square$ Arenosols $\square$ Leptosols $\square$ Fluvisols $\square$ Cambisols $\square$ Luvisols
$\square$ Acrisols $\square$ Chernozems $\square$ Nitisols $\square$ Plinthosols $\square$ Gleysols $\square$ Planosols

Figure 3 - Simulated 30 minutes rainfall intensity for return periods of 2 (a), 5 (b), 10 (c), 25 (d), 50 (e) and 100 (f) years and the soils types in the MATOPIBA region. Adapted from IBGE (2012).

increase by convective of frontal systems originated from south and north hemisphere (Namias, 1972b; Kousky, 1979), and convective complex formed in the African region associated with anti-cyclones (Molion and Bernardo, 2002). Otherwise, in the central-south of the MATOPIBA, the rainfall intensity is affected by frontal 
systems remained between $5^{\circ} \mathrm{S}$ and $18^{\circ} \mathrm{S}$ and local convective (Oliveira, 1986), leading for lower rainfall intensity.

\subsection{Erosion risk by erosivity and erodibility}

The rainfall intensity of $50 \mathrm{~mm} \mathrm{~h}^{-1}$ occurred in the most rainfall gauges of MATOPIBA, when considered return periods of 2 year (Fig. 3). Nearing et al. (2017) observed that the maximum energy for erosivity was reached when rainfall intensity was between 50 and $75 \mathrm{~mm} \mathrm{~h}^{-1}$, considering the methodologies of Universal Soil Loss Equation (USLE), Revised Universal Soil Loss Equation (RUSLE) and RUSLE 2. These conditions showed that, even under a low return period of two year, there was an event of maximum rainfall intensity that result in the maximum erosivity energy to cause soil erosion.

In the MATOPIBA, the main soil type were Ferralsols, Arenosol and Leptosols (Fig. 3). Ferralsols showed a mean (minimum-maximum) texture of $11 \%(1-37), 32 \%$ (6-82), 57\% (5-90) and 1.09\% (0.03-5.05), respectively, for silt, clay, sandy and organic matter content. These conditions lead an erodibility factor of 0.35 (Wanielista, 1978), classified as moderate risk (Jones et al., 1996). Leptosols also showed a moderate risk, with a mean texture of $30 \%$ (4-52), 22\% (1-47), 48\% (17-91) and 2.43\% (0.16-6.12), respectively, for silt, clay, sandy and organic matter content. Arenosols had a low risk, due to higher sand content of $87 \%$ (71-99), and low content of silt and clay, respectively, of $6 \%(1-17)$ and $7 \%(0-18)$, although low organic matter content of $0.71 \%(0.02-5.55)$.

The erosivity showed higher potential for erosion, as well as, the moderate erodibility for areas with Ferralsols and Leptosols. This demonstrates the importance to reduce the risk of other compements from the Universal Soil Loss Equation. The Universal Soil Loss Equation consider the erosivity, erodibility, slope steepness and length, land use and cropping management, and control erosion practices (Nearing et al., 2017). In these factors, the land use, cropping management and control practice are possible to be change to reduce erosion risk. The practices of zero tillage, mulching of crop residues and intercropping (Ward et al., 2018), construction of drains and culverts, contour drains and sowing, vegetation buffer, tree planting and land uses adequacy (Zwirtes et al., 2013; Fernandez, 2017) can be highlighted.

\section{Conclusion}

The maximum rainfall intensity was efficiently adjusted using the Gumbel probabilistic model for all rainfall gauges. Based on the Gumbel distribution model, the rainfall intensity-duration-frequency model had the parameters adjusted to estimate rainfall intensity for different duration and return period. The maximum rainfall intensity in 30 minutes for two year of return period showed a huge capacity to cause erosion, based on the maximum energy from erosivity. The erodibility risk was classified as moderate for Ferralsols and Leptosols, and low for Arenosols. The description of the maximum rainfall patterns through intensity-duration-frequency relationships can be used to dimension the size of the structure in agriculture areas and to adequate the land use, cropping management and control practice to reduce erosion, water losses and the vulnerability in rural areas.

\section{References}

ALVARES C.A.; STAPE J.L.; SENTELHAS P.C.; GONÇALVES J.L.M.; SPAROVEK G. Köppen's climate classification map for Brazil. Meteorologische Zeitschirift, v. 22, p. 711-728, 2013.

ANA - AGÊNCIA NACIONAL DE ÁGUAS. Hidroweb. Available at: [http://www.snirh.gov.br/hidroweb]. Accessed on: [April, 2014].

BEN-ZVI, A. Rainfall intensity-duration-frequency relationships derived from large partial duration series. Journal of Hydrology, v. 367, p. 104-114, 2009.

BESKOW, S.; CALDEIRA, T.L.; MELLO, C.R. DE; FARIA, L. C.; GUEDES, H.A.S. Multiparameter probability distributions for heavy rainfall modeling in extreme southern Brazil. Journal of Hydrology: Regional Studies, v. 4, p. 123133, 2015.

CAMPOS, A.R.; SANTOS, G.G.; SILVA, J.B.L.; IRENE FILHO, J.; LOURA, D.S. Equações de intensidade-duraçãofrequência de chuvas para o estado do Piauí. Revista Ciência Agronômica, v. 45, p. 488-498, 2014.

CARDOSO, C.O.; BERTOL, I.; SOCCOL, O.J.; SAMPAIO, C. A.P. Generation of intensity duration frequency curves and intensity temporal variability pattern of intense rainfall for Lages/SC. Brazilian Archives of Biology and Technology, v. 57, p. 274-283, 2014.

CONAB. Survey of Crop Season. Available at: [http://www. conab.gov. br/conteudos.php?a=1253\&]. Accessed on: [January, 2018].

DAEE/CETESB - DEPARTAMENTO DE ÁGUA E ENERGIA ELÉTRICA / COMPANHIA DE TECNOLOGIA DE SANEAMENTO AMBIENTAL. Drenagem urbana: Manual de projeto. DAEE-CETESB, São Paulo, 466 pp, 1980.

DAMÉ, R.C.F.; TEIXEIRA, C.F.A.; GONÇALVES, T.; SANTOS J.P.S.; QUADRO, M.S. Erosividade sob duas durações de intensidades máximas da chuva em Pelotas - RS. Revista Agroambiental On-line, v. 6, p. 1-8, 2012.

ELSEBAIE, I.H. Developing rainfall intensity-duration-frequency relationship for two regions in Saudi Arabia. Journal of King Sand University - Engineering Sciences, v. 24, p. 131-140, 2012.

FERNANDEZ, M.A. Adoption of erosion management practices in New Zealand. Land Use Policy, v. 63, p. 236-245, 2017.

IBGE. Interactive Maps: Soils. Available at: [http://mapas.ibge. gov.br]. Accessed on: [February, 2012].

INMET. Clima - Normais Climátologicas do Brasil. Available at: [http://www.inmet.gov.br/portal/index.php? $\mathrm{r}=$ clima/normaisClimatologicas]. Accessed on: [November, 2017]. 
JONES, D.S.; KOWALSKI，D.; SHAW， R.B. Calculating revised universal soil loss equations (RUSLE) estimates on Departament of Defense Lands: A review of Rusle factors and US Army Land Conditions- trend analysis (LCTA) data gaps. Departament of Forest Science, Colorado State University, Fort Collins, 9 p. 1996.

KOUSKY, V.E. Frontal Influences on Northeast Brazil. Monthly Weather review, v. 107, p. 1140-1153, 1979.

KOUTSOYIANNIS, D.; KOZONIS, D.; MANETAS, A. A mathematical framework for studying rainfall intensityduration-frequency relationships. Journal of Hydrology, v. 206, p. 118-135, 1998.

MAPA - MINISTÉRIO DA AGRICULTURA, PECUÁRIA E ABASTECIMENTO. Projeções do Agronegócio no Brasil - 2016/17 a 2026/27. MAPA. Brasília, 86 pp, 2017.

MAPA - MINISTÉRIO DA AGRICULTURA, PECUÁRIA E ABASTECIMENTO. Zoneamento Agrícola. Available at: [http://www.agricultura.gov.br/assuntos/riscos-seguro/ risco-agropecuario/portarias]. Accessed on: [August, 2018].

MOLION, L.C.B.; BERNARDO, S.O. A review of rainfall dynamics over northeastern Brazil. Revista Brasileira de Meteorologia, v. 17, p.1-10, 2002.

NAMIAS, J. Influence of northern hemisphere general circulation on drought in northeast Brazil. Tellus, v. 4, p. 336-343, 1972.

NEARING, M.A.; YIN, S-Q.; BORRELLI, P.; POLYAKOV, V. O. Rainfall erosivity: An historical review. Catena, v. 157, p. 357-362, 2017.

OLIVEIRA, A.S. Interações entre sistemas frontais na América do Sul e a convecção da Amazônia. Iin: Essay (Meteorology). INPE, São José dos Campos, 115 pp, 1986.

OLIVEIRA, L.F.C.; ANTONINI, J.C.A.; FLOREZE, A.P.; SILVA, M.A.S. Métodos de estimativa de precipitação máxima para o Estado de Goiás. Revista Brasileira de engenharia Agrícola e Ambiental, v. 12, p. 620-625, 2008.

OLIVEIRA, L.F.C.; CORTÊS, F.C.; WEHR, T.R.; BORGES, L. B.; SARMENTO, P.H.L. Intensidade-duração-frequência de chuvas intensas para localidades o Estado de Goiás e
Distrito Federal. Pesquisa Agropecuária Tropical, v. 35, p. 13-18, 2005.

RADAM. Levantamento de recursos naturais. Departamento Nacional da Produção Mineral (DNPM), Rio de Janeiro, 374 pp, 1974.

TFWALA, C.M.; VAN RENSBURG, L.D.; SCHALL, R.; MOSIA, S.M.; DLAMINI, P. Precipitation intensity-duration-frequency curves and their uncertainties for Ghaap plateau. Climate Risk Management, v. 16, p. 1-9, 2017.

WANG, H.; GAO, J.E.; ZHANG, M-J.; LI, X-H.; ZHANG, S-L. et al. Effects of rainfall intensity on groundwater recharge based on simulated rainfall experiments and a ground flow model. Catena, v. 127, p. 80-91, 2015.

WANIELISTA, M.P. Stormwater management: Quality and quantity. Ann Harbor Science Publishers, Michigan, 383 pp, 1978.

WARD, P.S.; BELL, A.R.; DROPPELMANN, K.; BENTON, T. G. Early adoption of conservation agriculture practices: Understanding partial compliance in programs with multiple adoption decisions. Land Use Policy, v. 70, p. 27-37, 2018.

WISCHMEIER, W.H.; SMITH, D.D.; UHLAND, R.E. Evaluation of factors in the soil-loss equation. Agricultural Engineering, v. 39, p. 458-462, 1958.

WU, Z.; WEI, Y.; WANG, J.; XIA, J.; CAI, C. et al. Effects of erosion degree and rainfall intensity on erosion processes for Ultisols derived from quaternary red clay. Agriculture, Ecosystems and Environment, v. 249, p. 226-236, 2017.

ZHENG, M.G.; CHEN, X. Statistical determination of rainfallrunoff erosivity indices for single storms in the Chinese loess plateau. Plos One, v. 10, n. 3, e0117989, 2015.

ZWIRTES, A.L.; SPOHR, R.B.; BARONIO, C.A.; MENEGOL, D.R.; DA ROSA, G.M. et al. Soil water infiltration measuments using the double ring and cornell infiltrometer in a Rhodic Hapludix. Semina: Ciências Agrárias, v. 34, n. 6, p. 3489-3499, 2013.

This is an Open Access article distributed under the terms of the Creative Commons Attribution License, which permits unrestricted use, distribution, and reproduction in any medium, provided the original work is properly cited. 